\title{
RULES AND CONDITIONS FOR PLACING ADVERTISEMENTS IN PUBLIC SPACE BASED ON EXAMPLES OF SELECTED POLISH CITIES
}

\author{
Monika Płuciennik, M.Sc. \\ Wroctaw University of Environmental and Life Sciences \\ e-mail:monika.pluciennik@upwr.edu.pl
}

\begin{abstract}
The changes in law introduced by the so-called "Act on Landscape Protection" (Act on amending certain acts in connection with the strengthening of landscape protection tools of 24 April 2015) obliged local territorial self-government units to define the rules and conditions regarding the placement of street furniture, signboards and other advertisement carriers and fencing. The aim of the discussed local legislation act is, in particular, to define urban space used for the display of advertisements along with the determination of the size, quality standards and type of construction materials from which signboards and other advertising devices may be produced. The determination of urban space for the display of advertisements is a broad and multi-faceted issue. There are certain limitations that hinder or prevent the placement of posters, banners, signboards or advertising panels in public space. The study presents the measures taken by local territorial self-government units with respect to the placement of advertisements in selected Polish cities and attempts to compare and evaluate the rules and conditions for placing signboards and advertising devices in public space.
\end{abstract}

Key words: landscape protection, outdoor advertising, public space, Act on landscape protection, rules and conditions of signboards locating.

JEL Classification: $O 21, R 00, R 58, R 59$.

Citation: Płuciennik M., 2018, Rules and Conditions for Placing Advertisement in Public Space Based on Examples of Selected Polish Cities, Real Estate Management and Valuation, vol. 26, no. 2, pp. 71-82.

DOI: $10.2478 /$ remav-2018-0017

\section{Introduction}

The first municipality in Poland to create an advertising code was the Municipality Ciechanów. This took place by virtue of Resolution No. 228/XIX/2016 of the Municipal Council of Ciechanów of April 28, 2016 on the principles and conditions for the placement of street furniture, signboards and advertising devices and fences, their sizes and quality standards. The aforementioned Resolution is a consequence of changes in selected legislation introduced by the so-called Act on Landscape Protection (Act on amending certain acts in connection with the strengthening of landscape protection tools from 24 April 2015).

The author understands the term "advertising code" as a set of guidelines, principles, conditions, restrictions and bans connected with the placement of various types of advertising signboards and devices (both free-standing and placed of the façades of buildings) in public space. One aspect of space management is the visibility of objects in the landscape. This factor can be expressed in a quantified manner, so as to objectively assess the impact of test items on the quality of space (KAZAK et al. 2017).

The objective of the possibility of adopting resolutions concerning the rules and conditions regarding the placement of street furniture, signboards and advertising devices and fencing offered by the legislator is to maintain spatial order, protect the urban landscape, protect the identity and 
tradition of a given location and improve the image of the city. Most towns in Poland struggle with the issue of advertising chaos. Studies by CHMIELEWSKI (CHMIELEWSKI et al. 2013) present the problem of visual aggression imposed by outdoor advertising and demonstrate the necessity of considering the possibility of implementing a system of evaluating the saturation of municipal areas with advertising content on a municipal administration level. According to CHMIELEWSKI, this would make it possible to issue decisions concerning the location, form, type and content of new advertising investments, not only in terms of the problem of the ownership title to the land on which the advertisement will be placed, but most importantly, in terms of the saturation of the given urban space with advertising content.

The problem of the visual aggression of outdoor advertising has been noticed throughout the world. Research has demonstrated that visual chaos within the road zone is one of the factors that distract the drivers' attention (COLE, HUGHES 1984; THEEUWES et al. 1998; BEIJER 2002; LEE et al. 2007; SHINAR 2007; EDQUIST 2009; SPEIRS et al. 2008). Hence, a further objective that would considerably influence the rules and conditions specified in the resolutions of municipal councils should be defined. This objective is to improve road safety by means of limiting the number of advertisements.

Advertisement affects humans by means of sensory (visual) overload - environmental stimuli (their number and efficiency) cause an excessive level of stimulation that exceeds the human capacity to remember and process them (MILGRAM 1970). Large-size advertisements, on the other hand, quite often restrict the functioning of apartment owners or tenants by depriving them of daylight. Due to this, the authors of the rules and conditions for the placement of advertisements should pay special attention to the psychological aspect of advertisements placed in space.

The determination of urban space for the display of advertisements is a broad and multi-faceted issue. There are certain limitations that hinder or prevent the placement of posters, banners, signboards or advertising panels in public space. They include requirements that are posed in order to ensure safety, protect cultural heritage or the natural environment and to preserve the rights of tenants and home owners. The study discusses the topic of solutions introduced by local territorial self-government units in terms of the rules and conditions for the placement of advertising in public space, as determined in newly created advertising codes.

\section{Methodology}

With the entry into force of the so-called Act on Landscape Protection, municipal councils were granted the power to determine the rules and conditions of locating street furniture, signboards and advertising devices as well as fences. A new local legislation act, prepared for the whole area of the municipality, will gather all these rules and conditions in a single document and lead to the separation of regulations from local spatial development plans.

As the process of preparing draft resolutions, followed by public consultations, is very timeconsuming, so far only few cities have adopted advertising codes.

The study attempts to compare and evaluate the rules and conditions for the placement of signboards and advertising devices in public space. The research took into account the adopted resolutions and published draft resolutions that are currently in the phase of public consultations in selected Polish cities (Table 1).

Table 1

Research area

\begin{tabular}{ccccc}
\hline City & City area [sqkm] & Population [thd] & Act level & Date \\
\hline Ciechanów & 32.51 & 43.9 & Act & 28.04 .2016 \\
\hline Gdańsk & 261.96 & 463 & Project of Act & February 2017 \\
\hline Kraków & 326.85 & 762 & Project of Act & April 2016 \\
\hline Lublin & 147.50 & 325 & Project of Act & November 2016 \\
\hline
\end{tabular}




\begin{tabular}{ccccc}
\hline Łódź & 293.25 & 699 & Project of Act & August 2016 \\
\hline Opole & 148.99 & 128 & Act & 29.12 .2016 \\
\hline Szczecin & 300.55 & 405 & Project of Act & June 2016 \\
\hline
\end{tabular}

\section{Source: Own study}

A comparative analysis of the collected information was conducted by comparing several versions of the rules and conditions for placing advertisements in public space, as proposed by different municipal councils, in order to find certain correlations, such as identity, similarity or difference between properties and facts.

The aim of the study is to present solutions related to the placement of advertisements in public space, and thus to spatial management in terms of the discussed matter. The analysis included seven cities: Ciechanow, Gdansk, Krakow, Lublin, Lodz, Opole and Szczecin (Fig. 1), which differ in terms of size and population, as well as spatial management, the degree of urbanization and historical values.

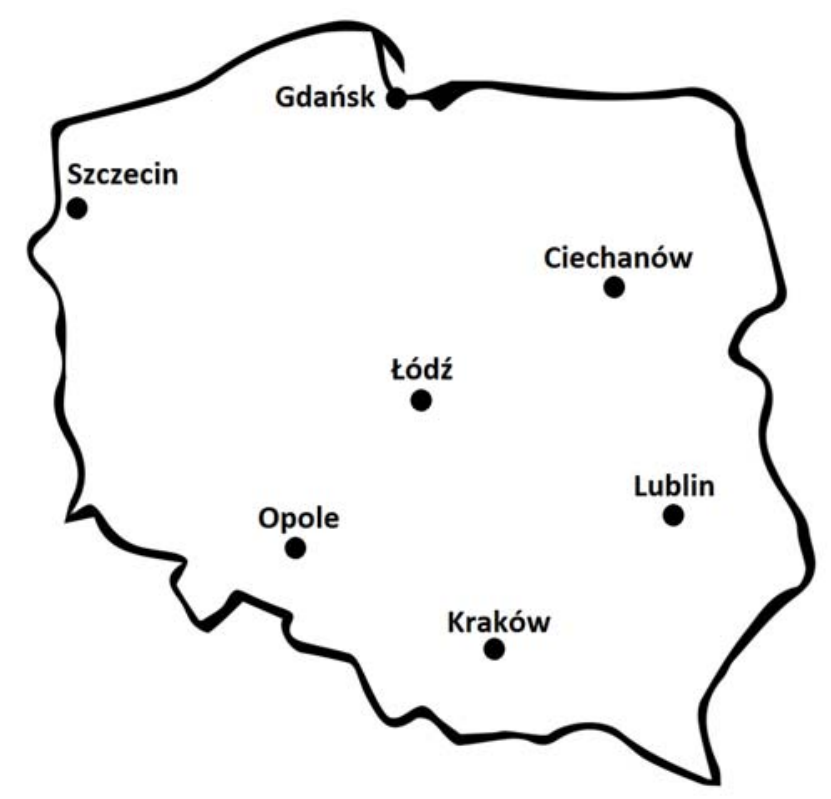

Fig. 1. Research area - selected cities. Source: own study.

3. Rules and conditions for the placement of signboards and advertising devices in selected Polish cities

\subsection{Zones for the placement of advertisements}

Pursuant to the provisions of the Act on Landscape Protection, the rules and conditions for the placement of signboards and advertising devices should be prepared for the whole area of the municipality. However, different regulations may be foreseen for various zones of the municipality, provided that the borders of these areas are clearly defined. Table 2 presents the assumptions adopted in selected cities with respect to the division of space into advertisement placement zones.

\subsection{Classification of signboards and advertising devices}

In order to give some order to the signboards and advertising devices placed in urban space, the authors of the discussed rules and conditions have taken attempts to classify them. Lublin was the only city where no attempt at classifying advertisements was made.

In Ciechanow, advertisements were classified according to the size of their display. The classification distinguishes between small format (advertising surface up to $2 \mathrm{~m}^{2}$ ), medium format 
$\left(2 \mathrm{~m}^{2}\right.$ to $\left.8 \mathrm{~m}^{2}\right)$ and large format $\left(8 \mathrm{~m}^{2}\right.$ to $\left.20 \mathrm{~m}^{2}\right)$, thus determining the maximum surface of an advertisement $\left(20 \mathrm{~m}^{2}\right)$.

Table 2

Advertisement placement zones

\begin{tabular}{ccc} 
City & $\begin{array}{c}\text { Amount of } \\
\text { zones }\end{array}$ & Division of advertisement placement zones \\
\hline Ciechanów & 1 & the same rules and conditions for whole area of the municipality \\
\hline Gdańsk & 7 & $\begin{array}{c}\text { natural-cultural landscape area, i.e. landscape parks, protected } \\
\text { landscape areas, urban parks, cemeteries (1); historic area (2); } \\
\text { historical architectural complex area(3); concentrated housing area } \\
(4) ; \text { sports and entertainment facilities area (5); distributed housing } \\
\text { area (6); industrial and service complexes area (7) }\end{array}$ \\
\hline Kraków & 4 & $\begin{array}{c}\text { protected landscape areas: historical (I), important (II), } \\
\text { environmental (III), local (IV) }\end{array}$ \\
\hline Lódź & 2 & $\begin{array}{c}\text { historical center of the city with its immediate surroundings area } \\
\text { (I); other area (II) }\end{array}$ \\
\hline Opole & 3 & $\begin{array}{c}\text { Cultural Park of Piotrowska St. (0); historical architectural } \\
\text { complexes area (I); other area (II) }\end{array}$ \\
\hline Szczecin & more than & many elementary zones in the city area (according to the graphic \\
appendix to the resolution)
\end{tabular}

Source: own study.
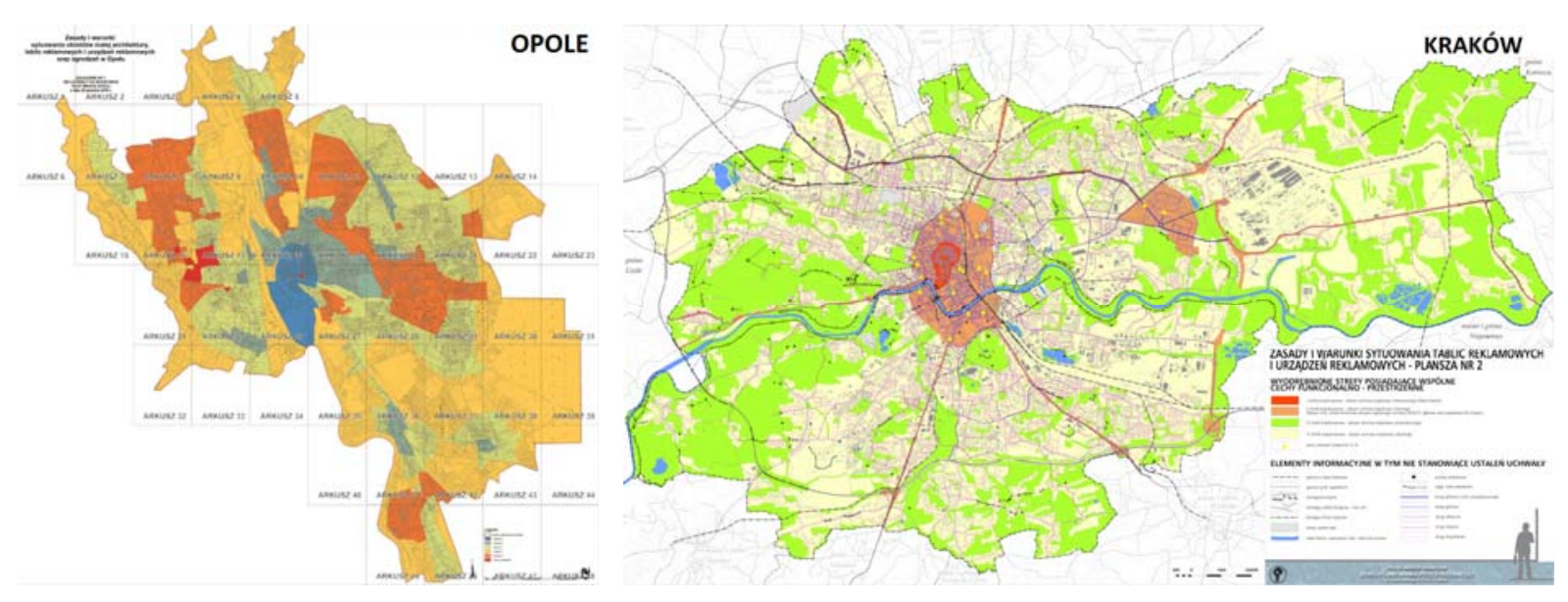

Fig. 2. Advertisement placement zones - example of Opole and Kraków. Source: www.bip.um.opole.pl; www.bip.krakow.pl.

In Krakow, the solution adopted to hierarchize advertisements was to divide them into freestanding advertisements, those placed on building façades and billboards. In Opole and Lodz, the classification is also based on advertisement type, although it is much more specific. It includes such categories as: advertising banners, billboards, cityscrolls, City Light Posters, displays, display cases, panels, logotypes, flagpoles, neon lights, posters, pneumatic advertising devices, pylons, building wraps, advertising columns, advertising stands, signs, advertising boards, totems and semaphores.

In Gdansk and Szczecin, advertisements have been classified according to type, similarly as in Opole and Lodz. However, additional classification according to advertising surface was introduced. 
In Gdansk, the following formats were distinguished: very small (up to $\left.0.1 \mathrm{~m}^{2}\right)$, small $\left(0.1 \mathrm{~m}^{2}\right.$ to $\left.1.0 \mathrm{~m}^{2}\right)$, Type A advertisements $(1.2 \mathrm{~m} \times 1.8 \mathrm{~m})$, Type B $(3.55 \mathrm{~m} \times 2.47 \mathrm{~m})$ and Type C $(5.04 \mathrm{~m} \times 2.38 \mathrm{~m}$ or $6.0 \mathrm{~m} \times 3.0 \mathrm{~m})$. In Szczecin, Type A $(1.2 \mathrm{~m} \times 1.8 \mathrm{~m})$, Type B $(3.6 \mathrm{~m} \times 2.5 \mathrm{~m})$, Type C $(6.0 \mathrm{~m} \times 3.0 \mathrm{~m})$ and Type $\mathrm{D}(12.0 \mathrm{~m} \times 3.0 \mathrm{~m}$ or $12.0 \mathrm{~m} \times 4.0 \mathrm{~m})$ advertisements were distinguished.

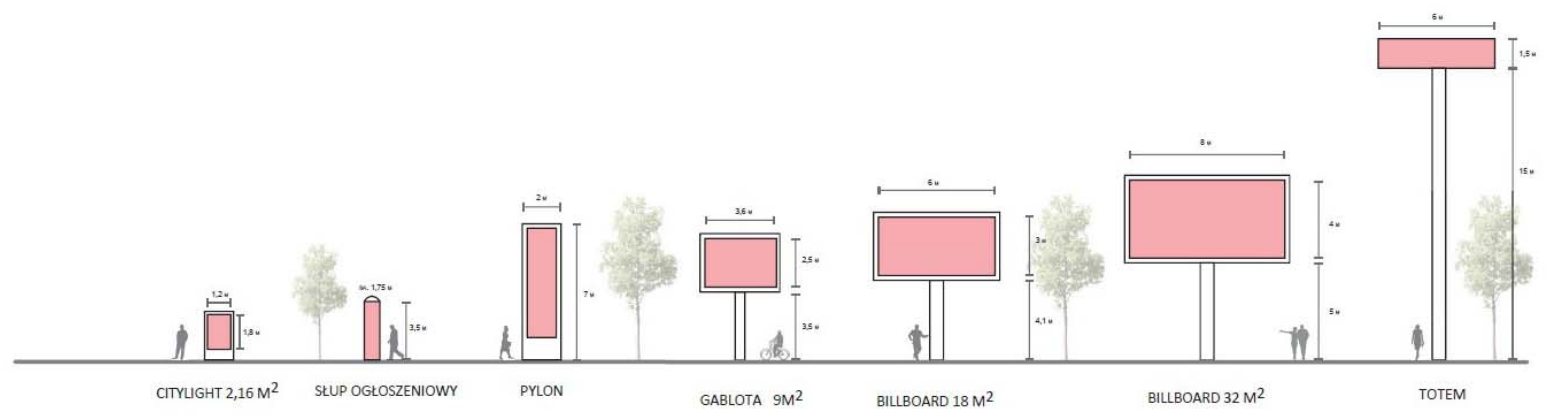

Fig. 3. Types of signboards and advertising devices in Gdańsk. Source: wwww.trojmiasto.pl.

\subsection{Quality standards and type of construction materials}

Resolutions of municipal councils should contain information determining the dimensions, quality standards and type of construction materials from which signboards and advertising devices can be made. Table 3 presents the discussed assumptions in the analyzed cities.

Quality standards and type of building materials

Table 3

\begin{tabular}{|c|c|c|c|}
\hline City & Quality standards & Building materials & Additional guidelines \\
\hline Ciechanów & high quality materials & metal, glass & $\begin{array}{l}\text { unitary for the whole } \\
\text { building in terms of } \\
\text { material, colors and graphics }\end{array}$ \\
\hline Gdańsk & $\begin{array}{l}\text { facade or white colored } \\
\text { advertisements, other } \\
\text { monochrome, sepia or } \\
\text { colorings taken from the } \\
\text { façade }\end{array}$ & not specified & $\begin{array}{l}\text { the use of protective fields, } \\
\text { detailed guidelines on the } \\
\text { separation between } \\
\text { advertising and other objects } \\
\text { on the facade or in the area }\end{array}$ \\
\hline Kraków & not specified & $\begin{array}{c}\text { wood, dibond, glass, } \\
\text { plexiglass, sheet metal, } \\
\text { aluminum, PVC, matt } \\
\text { window film }\end{array}$ & $\begin{array}{l}\text { unitary sizes, materials and } \\
\text { colors for the whole building }\end{array}$ \\
\hline Lublin & not specified & not specified & unitary sizes and colors \\
\hline Kódź & $\begin{array}{l}\text { high quality materials, } \\
\text { high level of aesthetics, } \\
\text { construction parts of } \\
\text { anthracite-gray color } \\
\text { (RAL 7016) }\end{array}$ & not specified & $\begin{array}{l}\text { adapting to architectural and } \\
\text { artistic composition }\end{array}$ \\
\hline Opole & $\begin{array}{l}\text { for area A: coloring in } \\
\text { shades of gray, white, } \\
\text { black, beige, bronze; for } \\
\text { other areas not specified }\end{array}$ & not specified & $\begin{array}{c}\text { unitary color, style, form, } \\
\text { typeface and material, } \\
\text { matched to the architectural } \\
\text { composition and character of } \\
\text { the building }\end{array}$ \\
\hline Szczecin & not specified & not specified & not specified \\
\hline
\end{tabular}

Source: own study. 


\subsection{Placement of advertisements in public space}

The main aim of advertising codes is to give some order to public space and to specify the potential locations for placing advertisements. The determination of the rules and conditions allows to protect the identity and to improve the image of a city, including the protection of: the existing social and spatial structure, tradition of a place, local culture, existing valuable objects and town-planning arrangements, and visual advantages of the town that are valuable from the historical and cultural point of view, as well as to create positive relations between public areas and privately owned real properties that surround them.

In order to achieve these objectives, each of the analyzed cities introduced a series of bans and restrictions concerning the placement of signboards and advertising devices. The restrictions are similar in all the discussed cases. In particular, it is absolutely forbidden to place advertisements on:

1. buildings subject to any of the forms of monument protection specified in Art. 7 of the Act on the Preservation of Historic Monuments of July 23, 2003,

2. areas of historical architectural complexes and historical urban arrangements,

3. areas of natural and landscape complexes or landscape parks,

4. greenery arrangements (trees, tree avenues, parks, green areas and their fences),

5. cemeteries and their fences,

6. bridges and overpasses

7. street light poles, utility network poles, transformer stations, etc.,

8. belts and barriers separating road lanes,

9. public transport stops.

Advertisements cannot be placed in a way that might interfere with the visibility of road signs, nor should they negatively affect plant vegetation conditions.

The advertising codes developed in the analyzed cities determine, to a more or less detailed extent, the rules and conditions for the placement of advertisements in specific town zones, taking into account the type of advertisement. Only in Lublin does the draft resolution foresee a ban on the placement of advertisements in the historical city centre, while in the remaining districts, compliance with the rules and conditions for the placement of signboards and advertising devices specified in local spatial development plans is required.

\subsubsection{Free-standing advertisements}

In the analyzed cities, the main requirement for placing a free-standing advertising device is to integrate it with the environment in a manner that does not interfere with the nature of the given location and does not obscure the view. Advertisements should be placed considering the management of the whole area and its neighborhood. They should not be in conflict with the spatial and communication structure. Moreover, advertisements within the given street should be uniformized in terms of form and color scheme. The resolutions also introduce limitations to the size or surface area.

In Opole, additional restrictions were introduced: free-standing boards can be placed in street space perpendicularly or parallel to existing space management elements, in particular to the axis or edge of a road, façades of buildings or a line of fencing. In Gdansk, legislators pay attention to the location of advertisement foundations that are placed below ground level.

\subsubsection{Advertisements on building façades}

In each of the analyzed cities, signboards and advertising devices placed on building façades should be integrated by maintaining the proportions and façade divisions. They should not obscure any important or characteristic architectural elements, such as windows, doors, cornices, windowsills, rustication, bannisters or shutters, and they should not interfere with the architectural consistency of the building. Selected resolutions define the percentage share of billboard and advertising device surface area in relation to the total surface area of the building façade. In Ciechanow, this is $20 \%$, in Opole $-20 \%$ or $30 \%$ depending on the zone, in Lodz - $25 \%$ of the façade surface area without windows and doors, but not more than $18 \mathrm{~m}^{2}$, and in Szczecin - 10\% of the surface area of the ground floor or basement façade.

Advertising codes also focus on advertisement stickers in windows and shop windows. In many cases, it is forbidden to cover windows and shop windows with visual information and advertisements in a manner that eliminates the window from the building composition and interferes 
with their essential function of providing daylight. In Lublin and Lodz, it is acceptable to cover up to $30 \%$ of the surface area, calculated separately for each window opening. In Opole, this applies to $20 \%$ or $30 \%$ respectively, depending on the given zone.

\subsubsection{Signs}

Pursuant to the provisions of the Act on Landscape Protection, it is impossible to forbid placing signs, i.e. signboards or advertising devices that inform users about the offices or agencies found inside a building, installed on the façade of the building. However, the resolution may specify the rules and conditions for the placement of such signs, as well as the dimensions and number of signs that may be placed on the given property by an entity that conducts business in it.

Advertising codes address the issue of locating signs in space. The main requirement for the placement of a sign on the façade of a building is that it should be integrated with the environment in a manner that does not interfere with the nature of the location and does not obscure objects entered in the register of monuments, statues, memorial signs, sculptures, fountains and national memorial sites. It is recommended to adapt the composition, size and color scheme of individual signs to the architectural arrangement, nature of the building and cross-section of the street. Signs placed in cultural heritage protection areas or on objects entered in the register of monuments of municipal register of monuments should have a form that carries historical references, adequate to the given area or object, in terms of style - or other, approved by the Conservator-Restorer.

Most of the cities have introduced a rule stating that only one sign may be placed on a given property by each entity that conducts business activity within the property. In Lublin, a maximum of two signs are allowed for each entity operating in the property, while in Opole - as many as three signs are permitted.

Most cities accept the use of signs that are either parallel (frieze display) or perpendicular (semaphore display) to the wall of the building. In Szczecin, it is permitted to place signs parallel to the façade or as free-standing signs placed on the land property in which the business is conducted.

Signs should be placed on the ground floor or basement façade, at the main entrance to the building. The resolutions of municipal councils specify the maximum dimensions of signs:

- in Ciechanow, the maximum dimensions must not exceed $100 \mathrm{~cm}$, provided that the sign surface cannot exceed $1.5 \mathrm{~m}^{2}$; the external edge of a semaphore sign cannot be further that $1 \mathrm{~m}$ away from the wall of the building;

- in Gdansk, the farthest part of a semaphore sign may be $1.2 \mathrm{~m}$ away from the building façade and the maximum sign area is $0.5 \mathrm{~m}^{2}$; the recommended formats are spatial letters or letters placed on a transparent background;

- in Krakow, it is permitted to place perpendicular signs (on jibs) the maximum dimensions of which do not exceed $80 \mathrm{~cm}$ length, measured from the façade of the building to the end of the jib with the sign, $60 \mathrm{~cm}$ in height, $15 \mathrm{~cm}$ in width; the surface area of signs on façades should not exceed $1 \mathrm{~m}^{2}$;

- in Lublin, the total surface area of signs must not exceed $10 \%$ of the surface of the façade in the orthogonal projection, provided that the height of lettering in the sign cannot exceed $0.5 \mathrm{~m}$ and the length of text cannot exceed $3.5 \mathrm{~m}$. Signs perpendicular to the façade cannot be extended more than $1.2 \mathrm{~m}$ from the façade.

- in Lodz, the surface of signs parallel to the wall of the building cannot exceed $3 \mathrm{~m}^{2}$ while the advertising area of semaphore signs cannot exceed $0.5 \mathrm{~m}^{2}$, and they can be placed, at maximum, $1 \mathrm{~m}$ away from the wall;

- in Opole, the maximum distance between the wall to the end of semaphore sign is $0.8 \mathrm{~m}$, while the maximum surface and dimensions of signs placed on building façades depend on the zone where the building is located;

- in Szczecin, it is permitted to place signs of a surface area not exceeding $0.3 \mathrm{~m}^{2}$, although specific rules and conditions may define other surface areas for signs.

\subsubsection{Portable advertisements}

The resolutions address the issue of portable boards and advertising devices that usually take the form of so-called "stumblers" (A-shaped boards). Their placement must endanger traffic and must not reduce the width of the traffic lane below minimum width. 
In Ciechanow, the placement of such signs is permitted only in pedestrian walkways no narrower than $2.5 \mathrm{~m}$. The advertising surface must not exceed $1 \mathrm{~m}^{2}\left(0.5 \mathrm{~m}^{2}\right.$ in conservator protection areas $)$ and their height must not exceed $120 \mathrm{~cm}$. In Opole, it is permitted to place a single advertising board per one service premises. The size of such advertising must not exceed $1.20 \mathrm{~m} \times 0.60 \mathrm{~m}$ and it should be placed directly next to the entrance. In Lodz, quality standards were additionally defined (durable and aesthetic materials) along with the times of placement (only during the working hours of the given service entity).

\subsubsection{Renovation wraps}

The Act on Landscape Protection specifies the types of advertisements that may be distinguished in public space. They include advertisements placed on the scaffolding, fence or equipment of the construction site. The developed advertising codes define the rules for placing these types of advertisements.

In Gdansk, the advertisement may be placed on surfaces not exceeding $30 \%$ of the building wrap, while the remaining area should contain a graphic depiction of the covered elements of the façade. Placing advertisements on building wraps is permitted only during the construction works and for a period not exceeding 12 months, with an obligation to maintain a 5-year advertising-free period starting from the end of the previous display of advertisement on scaffolding on the same façade. In Lodz, advertisements may be placed on building wraps for only a period of 8 months, but they may occupy up to $60 \%$ of the surface area of the wrap. In Szczecin, advertisements placed on building wraps may be displayed for a maximum period of 3 months and may cover $100 \%$ of the surface of the wrap. Finally, in Krakow, advertisements may occupy $50 \%$ of the wrap surface and may be displayed for 12 months.

\subsection{Distance from landmarks}

In each of the analyzed cities, one of the criteria for the determination of rules and conditions of placing signboards and advertising devices is the minimum distance between advertisements and various types of objects, and between the advertisements themselves. Specific distances from freestanding advertisements to other objects as specified in advertising codes are presented in Table 4. The codes also provide information about the distances and protective fields for advertisements placed on building façades.

Table 4

Characteristic distances of advertising from objects specified in the advertising codes

\begin{tabular}{|c|c|c|}
\hline $\begin{array}{c}\text { Object or characteristic } \\
\text { element }\end{array}$ & $\begin{array}{c}\text { Method of determining the } \\
\text { distance }\end{array}$ & Distance indicator \\
\hline road edge & $\begin{array}{l}\text { calculated perpendicular to the } \\
\text { edge of the roadway, distance } \\
\text { depending on the type of road }\end{array}$ & $\begin{array}{c}\text { Ciechanów: } 2 \mathrm{~m} \\
\text { Gdańsk: } 2 \mathrm{~m} \text { do } 14 \mathrm{~m} \\
\text { Kraków: } 3 \mathrm{~m}, 6 \mathrm{~m}, 8 \mathrm{~m}, 10 \mathrm{~m} \text {, } \\
20 \mathrm{~m}, 30 \mathrm{~m} \\
\text { Łódź: } 3 \mathrm{~m} \\
\text { Opole: } 3 \mathrm{~m} \\
\text { Szczecin: } 8 \mathrm{~m}, 12 \mathrm{~m}, 14 \mathrm{~m}, \\
\text { 16m, } 22 \mathrm{~m}, 32 \mathrm{~m}\end{array}$ \\
\hline crossroad & $\begin{array}{l}\text { from the beginning of the } \\
\text { crossroad (as the stop line), } \\
\text { distance depends on the } \\
\text { advertisements types }\end{array}$ & $\begin{array}{c}\text { Ciechanów: } 10 \mathrm{~m} \text { lub 20m } \\
\text { Gdańsk: } 70 \mathrm{~m} \\
\text { Kraków: } 50 \mathrm{~m} \\
\text { Łódź: } 50 \mathrm{~m} \\
\text { Opole: } 30 \mathrm{~m} \\
\end{array}$ \\
\hline traffic signs, traffic lights & straight line & $\begin{array}{l}\text { Ciechanów: } 15 \mathrm{~m} \\
\text { Łódź: } 20 \mathrm{~m}\end{array}$ \\
\hline $\begin{array}{c}\text { monuments, natural } \\
\text { monuments, memorial sites }\end{array}$ & straight line & $\begin{array}{l}\text { Ciechanów: } 50 \mathrm{~m} \\
\text { Łódź: } 50 \mathrm{~m}\end{array}$ \\
\hline historical architectural property & straight line & Kraków: 50m \\
\hline
\end{tabular}


facades with window

Rother signboards and advertisements devices straight line

Gdańsk: 5m, 10m
Ciechanów: 10m lub 30m

Gdańsk: 35m, 70m, 100m

straight line, distance depends on the advertisements types or the type of road
Kraków: 50m, 100m, 200m, $1000 \mathrm{~m}$

Łódź: 30m, 50m, 75m

Opole: 50m, 100m, 150m

Szczecin: 50m, 100m, 150m,

$300 \mathrm{~m}$

Source: own study.

\subsection{Period for adapting advertisements to the provisions of advertising codes}

The Act on Landscape Protection gives municipal councils the power to impose an obligation to adapt the signboards and advertising devices to the rules and conditions specified in the resolutions within a period of no less than 12 months from the entry into force of these resolutions.

The minimum statutory period for advertisement owners was foreseen in Ciechanow, Krakow and Lodz. In Lublin, this period is 12 months for advertisements placed in Zone I and 36 months for those placed in Zone II. In Opole, it is 30 months. In Gdansk, the period for adapting advertisements was defined depending on the type of advertisement: for signboards and advertising devices created pursuant to a valid building permit or an application to start construction works accepted by an organ of architecture and building administration - 24 months, for other signboards and advertising devices - 12 months. On the other hand, in Szczecin, advertisements placed before January 1st, 1989 and those placed after January 1st, 1989 pursuant to an application to start construction works not requiring a building permit, to which the organ of architecture and building management did not file an effective objection or pursuant to a decision on issuing a building permit, may remain in their current state, while others have to be adapted to the rules and conditions within 24 months.

\section{Discussion and conclusions}

The Act on Landscape Protection, which has been effective since September 11, 2015, was adopted to help local territorial self-governments give some order to advertising in public space and to care for spatial order and landscape protection. Its provisions gave municipal councils the power to create a single document for the whole administrative area, which will specify the rules and conditions for the placement of signboards and advertising devices.

Numerous Polish municipalities have appreciated the opportunities resulting from this new form of local law act and adopted resolutions on starting the development of rules and conditions of locating street furniture, signboards and advertising devices, as well as fences. The process of creating the discussed resolution is time-consuming, requiring numerous negotiations as well as public consultations. As a result, as of the date of our research, few municipalities had completed the works on advertising codes. The study compares the proposed solutions related to the placement of advertisements in Ciechanow, Gdansk, Krakow, Lublin, Lodz, Opole and Szczecin.

The first characteristic element of these resolutions is the division of the administrative areas of municipalities into advertisement placing zones. The analysis demonstrates that the statement that the number of zones increases with the surface area of a city is not true. In most cases, municipalities did not limit themselves to establishing continuous zones (exceptions: Lublin, Szczecin). Areas were characterized according to the type of landscapes they represent. Such a solution enabled basic rules to be introduced, such as the requirement to uniformize the formats of signboards and advertising devices and to define specific rules and conditions for areas that require decisive actions to improve the aesthetics of public space.

The next step in the resolution process was the classification of signboards and advertising devices. This was solved in two ways:

1. by classifying signboards and advertising devices according to their surface,

2. by classifying signboards and advertising devices according to their type.

Resolutions of municipal councils should contain information determining the dimensions, quality standards and type of construction materials from which signboards and advertising devices can be 
made. As far as quality standards are concerned, the main guidelines were to uniformize the signboards and advertising devices in terms of the materials, color schemes and graphics used and to adapt them to existing architectural and spatial divisions. The permitted colors of signboards and advertising devices were defined along with the type of acceptable construction materials.

The cities presented very different approaches to the possibility of placing advertisements in space. Nevertheless, provisions forbidding the placement of signboards and advertising devices were very consistent. First of all, they forbade the placing of advertisements on objects subject to monument protection, on objects of natural or historical significance, on arranged green areas, cemeteries and on public transport stops. Another important issue was the protection of view openings and points, and the requirement not to interfere with the nature of a given building or location.

The biggest differences were found in analyzing the rules concerning the distance between signboards and advertising devices from other characteristic objects. The most commonly listed objects were road edges, for which the distance from advertisements should range from $2 \mathrm{~m}$ to even $32 \mathrm{~m}$, depending on the type of road in question. Other important objects also included road junctions, road signs, traffic lights, and natural monuments, real properties subject to any forms of monument protection as well as other signboards and advertising devices.

The resolutions address the issue of placing signs in public space. It is permitted to place signs that are both parallel and perpendicular to the façade of the building, as well as free-standing signs in front of the main entrance to the building where the entrepreneur conducts business activity. Certain conditions were imposed to restrict the size and number of signs per each of the premises where business activity is conducted.

Resolutions also introduce the obligation to adapt signboards and advertising devices placed in public space to the rules and conditions specified therein. The minimum adaptation period specified in the Act on Landscape Protection is 12 months, but in certain cases, it was extended even up to 36 months.

In the opinion of the author, the adopted resolutions and proposed draft resolutions represent the correct direction of necessary changes in public space. A doubtless advantage of these solutions is the will to give some order to space and to care about its quality. The introduced bans and restrictions in placing advertisements will allow the advertising chaos that is certainly present in numerous Polish cities to be overcome. The determination of the maximum acceptable surface of signboards and advertising devices as well as the requirement to integrate advertisements with their surroundings or the façade of the building will enable opinion issuing authorities to manage public space in a balanced way. However, the determination of the maximum size of signs may be a barrier in adapting them to the size and divisions of the façade, and the lack of statutory obligation to adapt the signs to new requirements will lead to a diversity of external signage on building façades.

The development of the first advertising codes in Poland is a positive action that is worthy of replicating and the time and effort devoted to preparing them will result in improved quality of public space in the future. However, the authors of advertising codes did not take into account the requirements posed in order to ensure safety.

\section{References}

BEIJER D.D., 2002, Driver Distraction due to Roadside Advertising, University of Toronto, Department of Mechanical and Industrial Engineering.

CHMIELEWSKI S, CHMIELEWSKI T., J., 2013, Billboardy reklamowe w krajobrazie Lublina (Billboards in the Lublin Landscape), Problemy Ekologii Krajobrazu (Problems of Landscape Ecology) Vol. 36, pp. 109117.

Cole G. L., Hughens P.K., 1984, A Field Trial of Attention and Search Conspicuity, Human Factors, 26(3), pp. 299-313.

EDQUIST J., 2009, Visual Clutter in the Road Environment, Human Factors Workshop Presentation. Washington, DC: Transportation Research Board 88 ${ }^{\text {th }}$ Annual Meeting.

KAZAK J., VAN HOOL, J., SZEWRAŃSKI, S., 2017, Challenges in the Wind Turbines Location Process in Central Europe - The Use of Spatial Decision Support Systems, Renewable and Sustainable Energy Reviews, 76, pp. 425-433.

Lee S.E., McElhenY M.J., GiBSON R., 2007, Driving Performance and Digital Billboards, Center for Automative Safety Research. 
MiLGRAM S., 1970, The Experience of Living in Cities, Science, 167 after CZYŃSKI M., OSTROWSKI M., 2011, Reklama w przestrzeni publicznej miasta (Advertisement in the Public Space of a City), Przestrzeń i Forma (Space and Form), Vol. 16, pp. 213-228.

SHINAR D., 2007, Traffic Safety and Human Behavior, Amsterdam: Elsevier.

SPEIRS S., WINMILL A., KAZI T., 2008, The Impact of Roadside Advertising on Driver Distraction: Final Report, Basingstoke, Hampshire, Endgland: WSP Development and Transportation.

THEEUWES J., KRAMER A.F., HAHN S., IRWIN D.E., 1998, Our Eyes do not Always Go Where we Want them to Go: Capture of the Eyes by New Objects, Psychological Science, 9, 5, pp. 370-385.

Projekt Uchwały Rady Miasta Gdańska w sprawie zasad i warunków sytuowania obiektów małej architektury, tablic reklamowych $i$ urządzeń reklamowych oraz ogrodzeń, ich gabarytów, standardów jakościowych oraz rodzajów materiałów budowlanych, z jakich moga być wykonane (Project of Act of Gdańsk City Council on the rules and conditions for placement of street furniture, signboards and other advertisement carriers and fencing, their dimensions, quality standards and types of building materials which they can be made from), http://www.slideshare.net/ZDiZGdansk/projekt-uchwaykrajobrazowej-gdaska, accessed online 05.02.2017.

Projekt Uchwały Rady Miasta Krakowa w sprawie uchwalenia "Zasad i warunków sytuowania obiektów małej architektury, tablic reklamowych i urządzeń reklamowych oraz ogrodzeń" (Project of Act of Kraków City Council on the rules and conditions for the placement of street furniture, signboards and other advertisement carriers and fencing), https://www.bip.krakow.pl/?dok_id=71173, accessed online 05.02.2017

Projekt Uchwały Rady Miasta Lublin w sprawie zasad i warunków sytuowania obiektów małej architektury, tablic reklamowych i urządzeń reklamowych oraz ogrodzeń, ich gabarytów, standardów jakościowych oraz rodzajów materiałów budowlanych, z jakich moga być wykonane (Project of Act of Lublin City Council on the rules and conditions for placement of street furniture, signboards and other advertisement carriers and fencing, their dimensions, quality standards and types of building materials which they can be made from), http:/ /lublin.eu/lublin/przestrzen-miejska/aktualnosci/projekt-kodeksu-reklamowego-zblizasie-koniec-konsultacji,26,2133,1.html, accessed online 05.02.2017.

Projekt Uchwały Rady Miejskiej w Łodzi w sprawie ustalenia dla obszaru miasta Łodzi zasad $i$ warunków sytuowania obiektów małej architektury, tablic reklamowych i urządzeń reklamowych oraz ogrodzeń, ich gabarytów, standardów jakościowych oraz rodzajów materiałów budowlanych, z jakich moga być wykonane (Project of Act of Łódź City Council on the rules and conditions for the placement of street furniture, signboards and other advertisement carriers and fencing, their dimensions, quality standards and types of building materials which they can be made from), http://bip.uml.lodz.pl/_plik.php?id=45818, accessed online 05.02.2017.

Projekt Uchwały Rady Miasta Szczecin w sprawie ustalenia zasad i warunków sytuowania obiektów małej architektury, tablic reklamowych $i$ urządzeń reklamowych oraz ogrodzeń, ich gabarytów, standardów jakościowych oraz rodzajów materiałów budowlanych, z jakich mogą być wykonane, (Project of Act of Szczecin City Council on the rules and conditions for placement of street furniture, signboards and other advertisement carriers and fencing, their dimensions, quality standards and types of building materials which they can be made from), Portal Systemu Informacji Przestrzennej Miasta Szczecin (City of Szczecin Information System Web Portal) accessed online 10.02.2017.

Uchwała nr 228/XIX/2016 Rady Miasta Ciechanów z dnia 28 kwietnia 2016r. w sprawie zasad $i$ warunków sytuowania obiektów małej architektury, tablic reklamowych $i$ urządzeń reklamowych oraz ogrodzeń, ich gabarytów, standardów jakościowych oraz rodzajów materiałów budowlanych, z jakich mogq być wykonane (Act No. 228/XIX/2016 of 28 April 2016 of Ciechanów City Council on the rules and conditions for placement of street furniture, signboards and other advertisement carriers and fencing, their dimensions, quality standards and types of building materials which they can be made from)

Uchwała nr XXXVI/708/16 Rady Miasta Opola Rady Miasta Opola z dnia 29 grudnia 2016 r. o uchwaleniu uchwaty w sprawie zasad $i$ warunków sytuowania obiektów małej architektury, tablic reklamowych i urządzeń reklamowych oraz ogrodzeń (Act No. XXXVI/708/16 of 29 December 2016 of Opole City Council on the rules and conditions for placement of street furniture, signboards and other advertisement carriers and fencing).

Ustawa z dnia 24 kwietnia 2015 r. o zmianie niektórych ustaw w związku ze wzmocnieniem narzędzi ochrony krajobrazu (Act of April 2015 on amending certain acts in connection with the strengthening of the tools of landscape protection ) Dz. U. 2015, poz. 774 ze zm. (2015 Journal Of Laws, item 774 as amended). 
Ustawia z dnia 23 lipca 2003 r. o ochronie zabytków i opiece nad zabytkami (Act of July 23, 2003 on the Protection and Conservation of Monuments), Dz. U. z 2014 r. poz. 1446 oraz z 2015 r. poz. 397 (consolidated text, 2014 Journal Of Laws, item 1446 and 2015 item 397).

Ustawa z dnia 27 marca 2003 r. o planowaniu i zagospodarowaniu przestrzennym (Act of March 27, 2003 on Spatial Planning and Development), Dz. U. 2015 r. poz. 199 z późn. zm. (consolidated text, 2015 Journal Of Laws, item 199 as amended).

Ustawa z dnia 12 stycznia 1991 r. o podatkach i opłatach lokalnych (Act of January 12, 1991 on Local Taxes and Fees), Dz. U. 2014 poz. 849 ze zm. (consolidated text, 2014 Journal Of Laws, item 849 as amended). 